\title{
Applying Hyperaccumulator Straw in Cd-Contaminated Soil Enhances Nutrient Uptake and Soil Enzyme Activity of Capsella bursa-pastoris
}

\author{
Jin Wang ${ }^{1, a}$, Keng Wen ${ }^{1, b}$, Jun Shi ${ }^{2, c}$ and Xiulan Lv ${ }^{3, d *}$ \\ ${ }^{1}$ College of Horticulture, Sichuan Agricultural University, Chengdu, Sichuan, China \\ ${ }^{2}$ Mianyang Academy of Agricultural Sciences, Mianyang, Sichuan, China \\ ${ }^{3}$ Institute of Pomology and Olericulture, Sichuan Agricultural University, Chengdu, Sichuan, China

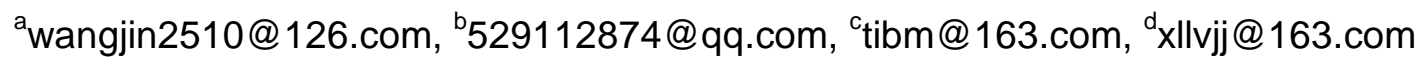 \\ ${ }^{*}$ Corresponding author
}

Keywords: Hyperaccumulator straw; Cadmium contamination; Capsella bursa-pastoris; Nutrient; Soil enzyme activity

Abstract. The effects of applying four hyperaccumulator species (Solanum photeinocarpum, Bidens pilosa, Siegesbeckia orientalis and Youngia erythrocarpa) straws in cadmium (Cd) contaminated soil on phosphorus ( $\mathrm{P}$ ) and potassium $(\mathrm{K})$ uptake and soil enzyme activity of Capsella bursa-pastoris were studied through a pot experiment. Five treatments were used in the experiment: control (no straw applied), and straw applied for each of the four hyperaccumulator species (S. photeinocarpum , $B$. pilosa, $S$. orientalis and $Y$. erythrocarpa). When applying the four hyperaccumulator species straws, the total $\mathrm{P}$ and $\mathrm{K}$ contents in roots, stems and leaves of $C$. bursa-pastoris increased compared with control. The total P and K contents in roots, stems and leaves of $C$. bursa-pastoris were ranked as: $S$. photeinocarpum straw $>Y$. erythrocarpa straw $>B$. pilosa straw $>S$. orientalis straw $>$ control. The soil available $\mathrm{P}$ and $\mathrm{K}$ contents were also increased by the four hyperaccumulator species straws. The four hyperaccumulator species straws enhanced soil sucrase, soil catalase and soil urease activities. Therefore, applying hyperaccumulator straw could used to increase nutrient content and enhance soil enzyme activity of $C$. bursa-pastoris in Cd-contaminated soil, and the straw of $S$. photeinocarpum was the best.

\section{Introduction}

Applying straw into soil is a commonly used measure of agricultural production [1]. After applying straw, significant amount of carbon, nitrogen, phosphorus, potassium and other nutrients are released by soil microbial action, and thus improve soil fertility [2]. Meanwhile, the straw also improves the soil enzyme activity, the number of micro-organisms and the effectiveness of soil nutrients, and thereby improves soil physical and chemical properties [3]. These results indicate that applying the plant straw into soil can change the biological effectiveness of various elements, and affect the nutrient elements absorption of plant.

The summer growth cadmium (Cd) hyperaccumulator plants Youngia erythrocarpa [4], Bidens pilosa [5], Solanum photeinocarpum [6] and Siegesbeckia orientalis [7] have strong tolerance to Cd. In this study, we applied the straw made from the shoots of Y. erythrocarpa, B. pilosa, $S$. photeinocarpum and $S$. orientalis into Cd-contaminated soil and planted the winter growth Cd-accumulator plant Capsella bursa-pastoris [8]. The aim of the study was to determine if application of straw from the hyperaccumulator species could efficiently promote the phosphorus $(\mathrm{P})$ and potassium $(\mathrm{K})$ uptake and soil enzyme activity of $C$. bursa-pastoris, and improve the phytoremediation ability of $C$. bursa-pastoris.

\section{Materials and Methods}

Materials. In August 2013, the shoots of S. photeinocarpum, B. pilosa, S. orientalis and Y. erythrocarpa were collected from the Ya'an campus farm of the Sichuan Agricultural University 
$\left(29^{\circ} 59^{\prime} \mathrm{N}, 102^{\circ} 59^{\prime} \mathrm{E}\right)$, China, from uncontaminated soil areas. The collected shoots of these plants were dried at $80{ }^{\circ} \mathrm{C}$ to constant weight, finely ground and sieved through a 5-mm-mesh nylon sieve. Capsella bursa-pastoris seedlings with two euphyllas were collected from the Ya'an campus farm (from uncontaminated soil) in September 2013. The inceptisol soil samples were collected from Ya'an campus farm in August 2013. The basic properties of the soil were the same as reference [4].

Experimental Design. The experiment was conducted at the Ya'an campus farm from August to October in 2013. The soil samples were air-dried and passed through a 5-mm sieve. Three kilograms of the air-dried soil was weighed into each polyethylene pot (15 cm high, $18 \mathrm{~cm}$ in diameter). $\mathrm{Cd}$ was added to soils as $\mathrm{CdCl}_{2} \cdot 2.5 \mathrm{H}_{2} \mathrm{O}$ at $50 \mathrm{mg} / \mathrm{kg}$. The pots were soaked in the $\mathrm{Cd}$ solutions for 4 weeks, and then the soil in each pot was mixed with the powdered shoots of the studied plants. Six-gram shoots were applied to each pot ( $2 \mathrm{~g}$ shoots per $\mathrm{kg}$ soil), and the soil moisture was maintained at $80 \%$ of field capacity for 1 week. The five experimental treatments in the experiment were control (no straw applied), applying $S$. photeinocarpum straw, applying B. pilosa straw, applying $S$. orientalis straw and applying $Y$. erythrocarpa straw. Each treatment was replicated three times using a completely randomized design with $10-\mathrm{cm}$ spacing between pots. Four uniform seedlings of C. bursa-pastoris were transplanted into each pot and the soil moisture content was maintained at $80 \%$ of field capacity from the time the plants were transplanted into the pots until the time the plants were harvested. At maturity (after $35 \mathrm{~d}$ ), the entire plants were harvested for determining contents of total $\mathrm{P}$ and $\mathrm{K}$ in roots and shoots [9]. The soil samples were collected for determining soil available P and K contents [9] and soil enzyme activity [10].

\section{Results and Discussion}

Total $\mathbf{P}$ content in $\boldsymbol{C}$. bursa-pastoris. Applying hyperaccumulator straw in Cd-contaminated soil increased total $\mathrm{P}$ contents in roots, stems and leaves of $C$. bursa-pastoris compared with control (Table 1). The total $\mathrm{P}$ contents in roots, stems and leaves of $C$. bursa-pastoris were ranked as: $S$. photeinocarpum straw $>Y$. erythrocarpa straw $>$ B. pilosa straw $>S$. orientalis straw $>$ control. Applying straws of $S$. photeinocarpum, B. pilosa, $S$. orientalis and $Y$. erythrocarpa in Cd-contaminated soil increased the total P content in roots of $C$. bursa-pastoris by $47.51 \%(p<0.05)$, $9.09 \%(p>0.05), 4.40 \%(p>0.05)$ and $22.29 \%(p<0.05)$ respectively compared with control, total $\mathrm{P}$ content in stems increased by $19.31 \%(p<0.05), 11.53 \%(p>0.05), 9.66 \%(p>0.05)$ and $12.15 \%$ $(p>0.05)$ respectively, and total $\mathrm{P}$ content in leaves increased by $45.87 \%(p<0.05), 31.02 \%(p<$ $0.05), 18.81 \%(p<0.05)$ and $37.95 \%(p<0.05)$ in leaves respectively.

Table 1 Total P content in C. bursa-pastoris

\begin{tabular}{|l|l|l|l|}
\hline Treatments & Roots $(\mathrm{g} / \mathrm{kg})$ & Stems $(\mathrm{g} / \mathrm{kg})$ & Leaves $(\mathrm{g} / \mathrm{kg})$ \\
\hline Control & $3.41 \pm 0.16 \mathrm{c}$ & $3.21 \pm 0.09 \mathrm{~b}$ & $3.03 \pm 0.30 \mathrm{~d}$ \\
\hline S. photeinocarpum & $5.03 \pm 0.13 \mathrm{a}$ & $3.83 \pm 0.11 \mathrm{a}$ & $4.42 \pm 0.08 \mathrm{a}$ \\
\hline B. pilosa & $3.72 \pm 0.24 \mathrm{bc}$ & $3.58 \pm 0.30 \mathrm{ab}$ & $3.97 \pm 0.10 \mathrm{bc}$ \\
\hline S. orientalis & $3.56 \pm 0.19 \mathrm{c}$ & $3.52 \pm 0.10 \mathrm{ab}$ & $3.60 \pm 0.13 \mathrm{c}$ \\
\hline Y. erythrocarpa & $4.17 \pm 0.26 \mathrm{~b}$ & $3.60 \pm 0.14 \mathrm{ab}$ & $4.18 \pm 0.11 \mathrm{ab}$ \\
\hline
\end{tabular}

Values are means of three replicate pots. Different lowercase letters indicate significant differences based on one-way analysis of variance in SPSS 13.0 followed by the least significant difference test $(p<0.05)$.

Total K content in $\boldsymbol{C}$. bursa-pastoris. When applying hyperaccumulator straw in Cd-contaminated soil, the total K contents in roots, stems and leaves of $C$. bursa-pastoris increased (Table 2). The total $\mathrm{K}$ contents in roots, stems and leaves of $C$. bursa-pastoris were ranked as: $S$. photeinocarpum straw > $Y$. erythrocarpa straw $>$ B. pilosa straw $>S$. orientalis straw $>$ control, which was the same as total $P$ content in C. bursa-pastoris. Applying straws of S. photeinocarpum, B. pilosa, S. orientalis and $Y$. erythrocarpa in Cd-contaminated soil increased the total $\mathrm{K}$ content in roots of C. bursa-pastoris by 
$15.07 \%(p<0.05), 6.71 \%(p>0.05), 2.88 \%(p>0.05)$ and $12.88 \%(p<0.05)$ respectively compared with control, total $\mathrm{K}$ content in stems increased by $31.23 \%(p<0.05), 22.41 \%(p<0.05), 5.17 \%(p>$ $0.05)$ and $26.05 \%(p<0.05)$ respectively, and total K content in leaves increased by $15.44 \%(p<0.05)$, $8.08 \%(p<0.05), 6.63 \%(p>0.05)$ and $9.53 \%(p<0.05)$ in leaves respectively.

Table 2 Total K content in C. bursa-pastoris

\begin{tabular}{|l|l|l|l|}
\hline \multicolumn{1}{|c|}{ Treatments } & Roots $(\mathrm{g} / \mathrm{kg})$ & Stems $(\mathrm{g} / \mathrm{kg})$ & Leaves $(\mathrm{g} / \mathrm{kg})$ \\
\hline Control & $7.30 \pm 0.14 \mathrm{~b}$ & $5.22 \pm 0.13 \mathrm{~b}$ & $8.29 \pm 0.31 \mathrm{c}$ \\
\hline S. photeinocarpum & $8.40 \pm 0.28 \mathrm{a}$ & $6.85 \pm 0.08 \mathrm{a}$ & $9.57 \pm 0.34 \mathrm{a}$ \\
\hline B. pilosa & $7.79 \pm 0.30 \mathrm{ab}$ & $6.39 \pm 0.17 \mathrm{a}$ & $8.96 \pm 0.23 \mathrm{ab}$ \\
\hline S. orientalis & $7.51 \pm 0.23 \mathrm{~b}$ & $5.49 \pm 0.14 \mathrm{~b}$ & $8.84 \pm 0.18 \mathrm{bc}$ \\
\hline Y. erythrocarpa & $8.24 \pm 0.37 \mathrm{a}$ & $6.58 \pm 0.35 \mathrm{a}$ & $9.08 \pm 0.11 \mathrm{ab}$ \\
\hline
\end{tabular}

Values are means of three replicate pots. Different lowercase letters indicate significant differences based on one-way analysis of variance in SPSS 13.0 followed by the least significant difference test $(p<0.05)$.

Soil available P content. Compared with control, when applying the four hyperaccumulator species straws in Cd-contaminated soil, the soil available $\mathrm{P}$ content increased (Fig. 1). The soil available $\mathrm{P}$ content was ranked as: $S$. photeinocarpum straw $>$ Y. erythrocarpa straw $>$ B. pilosa straw $>S$. orientalis straw > control.

Soil available $\mathbf{K}$ content. The soil available $\mathrm{K}$ content increased compared with control when applying the four hyperaccumulator species straws in Cd-contaminated soil (Fig. 2). The soil available K content was also ranked as: $S$. photeinocarpum straw $>Y$. erythrocarpa straw $>$ B. pilosa straw $>S$. orientalis straw > control. Compared with control, the soil available K content of applying straws of $S$. photeinocarpum, B. pilosa, S. orientalis and $Y$. erythrocarpa increased by $7.00 \%(p<0.05), 2.26 \%$ $(p>0.05), 0.78 \%(p>0.05)$ and $5.84 \%(p<0.05)$ respectively.

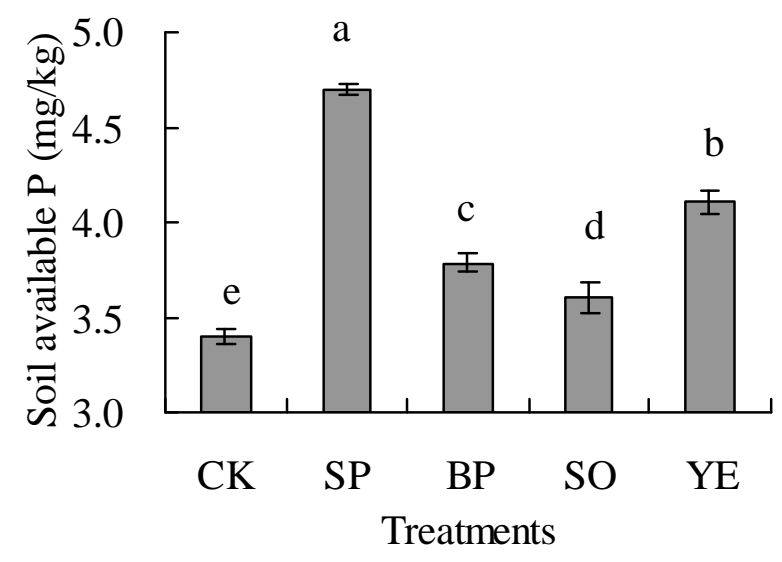

Fig. 1 Soil available K. Values are means of three replicate pots. Different lowercase letters indicate significant differences based on one-way analysis of variance in SPSS 13.0 followed by the least significant difference test $(p<0.05)$. $\mathrm{CK}=$ control, $\mathrm{SP}=S$. photeinocarpum, $\mathrm{BP}=$ B. pilosa, $\mathrm{SO}=$ S. orientalis, $\mathrm{YE}$ $=$ Y. erythrocarpa .

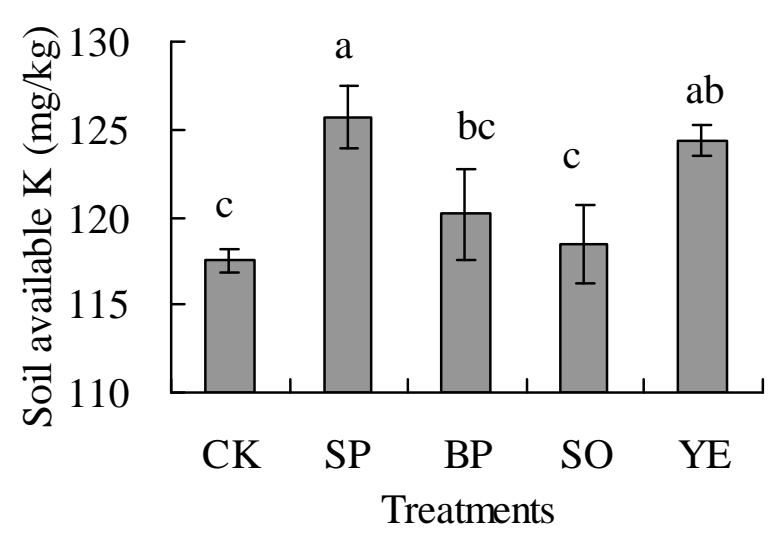

Fig. 2 Soil available K. Values are means of three replicate pots. Different lowercase letters indicate significant differences based on one-way analysis of variance in SPSS 13.0 followed by the least significant difference test $(p<0.05)$. CK $=$ control, $\mathrm{SP}=S$. photeinocarpum, $\mathrm{BP}=B$. pilosa, $\mathrm{SO}=S$. orientalis, $\mathrm{YE}=$ Y. erythrocarpa. 
Soil enzyme activity. The four hyperaccumulator species straws enhanced soil sucrase, soil catalase and soil urease activities of Cd-contaminated soil (Table 3). The soil sucrase activity was ranked as: $S$. photeinocarpum straw $>$ B. pilosa straw $>Y$. erythrocarpa straw $>S$. orientalis straw $>$ control, soil urease activity was ranked as: $S$. photeinocarpum straw $>B$. pilosa straw $>S$. orientalis straw $>Y$. erythrocarpa straw $>$ control, and soil catalase activity was ranked as: $Y$. erythrocarpa straw $>S$. orientalis straw $>$ S. photeinocarpum straw $>$ B. pilosa straw $>$ control.

Table 3 Soil enzyme activity

\begin{tabular}{|l|c|c|c|}
\hline \multicolumn{1}{|c|}{ Treatments } & $\begin{array}{c}\text { Soil sucrase activity } \\
(\mathrm{mg} / \mathrm{g})\end{array}$ & $\begin{array}{c}\text { Soil urease activity } \\
(\mathrm{mg} / \mathrm{g})\end{array}$ & $\begin{array}{c}\text { Soil catalase activity } \\
(\mathrm{ml} / \mathrm{g})\end{array}$ \\
\hline Control & $0.474 \pm 0.006 \mathrm{~d}$ & $0.398 \pm 0.013 \mathrm{e}$ & $0.262 \pm 0.025 \mathrm{c}$ \\
\hline S. photeinocarpum & $0.776 \pm 0.009 \mathrm{a}$ & $1.605 \pm 0.036 \mathrm{a}$ & $0.304 \pm 0.005 \mathrm{~b}$ \\
\hline B. pilosa & $0.735 \pm 0.005 \mathrm{a}$ & $1.451 \pm 0.033 \mathrm{~b}$ & $0.274 \pm 0.011 \mathrm{bc}$ \\
\hline S. orientalis & $0.531 \pm 0.033 \mathrm{c}$ & $0.958 \pm 0.020 \mathrm{c}$ & $0.348 \pm 0.007 \mathrm{a}$ \\
\hline Y. erythrocarpa & $0.624 \pm 0.024 \mathrm{~b}$ & $0.595 \pm 0.034 \mathrm{~d}$ & $0.379 \pm 0.016 \mathrm{a}$ \\
\hline
\end{tabular}

Values are means of three replicate pots. Different lowercase letters indicate significant differences based on one-way analysis of variance in SPSS 13.0 followed by the least significant difference test $(p<0.05)$.

\section{Conclusions}

When applying the four hyperaccumulator species (S. photeinocarpum, B. pilosa, S. orientalis and $Y$. erythrocarpa) straws in Cd-contaminated soil, the total $\mathrm{P}$ and $\mathrm{K}$ contents in roots, stems and leaves of C. bursa-pastoris increased compared with control. The soil available $\mathrm{P}$ and $\mathrm{K}$ contents were also increased by the four hyperaccumulator species straws. The four hyperaccumulator species straws enhanced soil sucrase, soil catalase and soil urease activities. Therefore, applying hyperaccumulator straw could used to increase nutrient content and enhance soil enzyme activity of C. bursa-pastoris in Cd-contaminated soil, and the S. photeinocarpum straw was the best.

\section{References}

[1] Z.Q. Dong, H.X. Zhu, X.X. Bai, L. Liu and Y. Liu: Chinese Agricultural Science Bulletin Vol. 30 (2014), p. 77.

[2] A.L. Wu, J.S. Wang, X.Y. Jiao, E.W. Dong, L.G. Wang, X. Han and Q. Chen: Chinese Journal of Eco-Agriculture Vol. 22 (2014), p. 744.

[3] T. Wei, L.N. Han, Q.F. Han, Z.K. Jia, R. Zhang, J.F. Nie and B.P. Yang: Plant Nutrition and Fertilizer Science Vol. 18 (2012), p.611.

[4] L.J. Lin, B. Ning, M.A. Liao, Y.J. Ren, Z.H. Wang, Y.J. Liu, J. Cheng and L. Luo: Environmental Monitoring and Assessment Vol. 187 (2015), p. 4205.

[5] Y.B. Sun, Q.X. Zhou, L. Wang and W.T. Liu: Journal of Hazardous Materials Vol. 161 (2008), p. 808.

[6] X.F. Zhang, H.P. Xia, Z.A. Li, P. Zhuang and B.Gao: Journal of Hazardous Materials Vol. 189 (2011), p. 414.

[7] S.R. Zhang, H.C. Lin, L.J. Deng, G.S. Gong, Y.X. Jia, X.X. Xu, T. Li, Y. Li and H. Chen: Ecological Engineering Vol. 51 (2013), p. 133.

[8] Y. Liu, L. Lin, Q. Jin and X. Zhu: Environmental Progress \& Sustainable Energy Vol. 34 (2015), p. 663. 
[9] S.D. Bao: Agrochemical Soil Analysis ( ${ }^{\text {rd }}$ edition, China Agriculture Press, Beijing 2000). [10]L.K. Zhou: Soil Enzymology (Science Press, Beijing 1987). 